\title{
役職別のストレス・レベル（第2 報)
}

馬目太永 1）＼cjkstart相崎雄二 2）＼cjkstart田中正敏 3）
1）舞子浜病院、舞子浜労衝衛生コンサルタント事務所
2）相崎医院
3）福島県立医科大学衛生学講座

前回の産業衛生学会において、自動車部品製造販売会社（O 社）の課長職のストレス点数が高く、係長職・部長職 ではストレス点数は低いことを報告した（図 1.)。そこで今回、役職別に職場に関する意識調查を行った。［対象と 方法］対象は $\mathrm{O}$ 社の労働者 149 名である。調査は自記式・匿名とし、 調査結果を直接調査責任者一郵送する方法をとり、個人の守秘を尊 重した。[結果］(1)回収率：149名中の有効回答は 131 名（有効回 収率 $87.9 \%$ ）であった。役職別にみると、一般は 95 名、係長職は 11 名、課長職は 17 名、部長職は 7 名、および不明 1 名であった。 (2)職場環境調査（表 1.）：係長と比較すると、課長職では「仕事で神 経をすり減らす」、仕事量が多すぎる」、「周囲が働きを認めてくれ ない」「上司に気を使う」などの項目を訴えた割合が高かった。「勤 務時間は適当である」と答えたのは係長に多く、逆に「勤務は不規 則」と答えたのは課長に多かった。[まとめ] 課長職では仕事量が多 く神経をすり減らし、それに比べて自分の働きを認めてくれないと 考えている労働者が多かった。

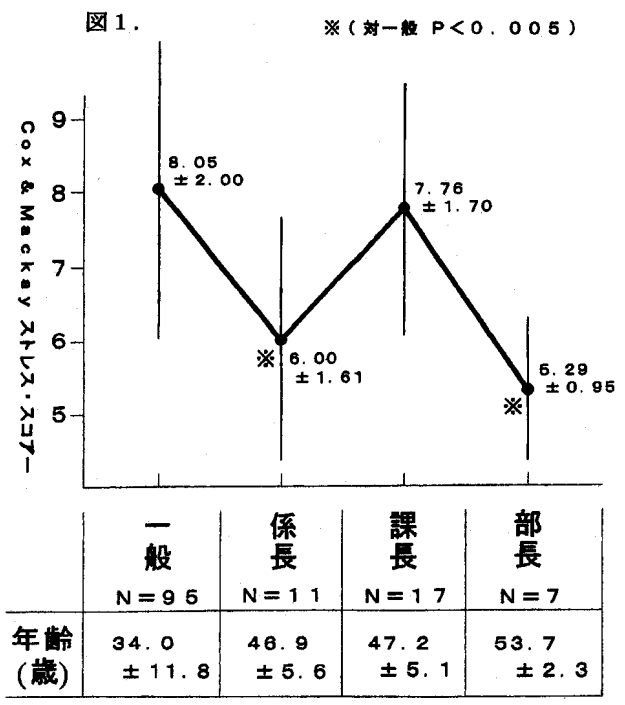

役職別にみた Cox \& Mackay ストレス スコアーと年踚

表 1 . 職場に関する意識調查

\begin{tabular}{|c|c|c|c|c|}
\hline & 一般 & 係長 & 課長 & 部長 \\
\hline & $N=95(\%)$ & $N=11(\%)$ & $N=17(\%)$ & $N=7(\%)$ \\
\hline 1)職場は自分に合っている。 & $75(78.9)$ & $8(72.7)$ & $15(88.2)$ & $7(100)$ \\
\hline 2)職場を変わりたい。 & $38(40.0)$ & $4(36.4)$ & $6(35.3)$ & $0(0.0)$ \\
\hline 3）収入に満足している。 & $15(15.8)$ & $1(9.1)$ & $3(17.6)$ & $4(57.1)$ \\
\hline 4)昇進·昇級がおそい。 & $45(47.4)$ & $6(54.5)$ & $7(41.2)$ & $1(14.3)$ \\
\hline 5)低ポストで不満。 & $25(26.3)$ & $1(9.1)$ & $0(0.0)$ & $1(14.3)$ \\
\hline 6)仕事内容に興味がある。 & $57(60.0)$ & $10(90.9)$ & $15(88.2)$ & $7(100)$ \\
\hline 7)仕事で神経をすり減らす。 & $44(46.3)$ & $3(27.3)$ & $15(88.2)$ & $5(71.4)$ \\
\hline 8)仕事の量が多すぎる。 & $35(36.8)$ & $3(27.3)$ & $11(64.7)$ & $2(28.6)$ \\
\hline 9)周囲が働きを認めてくれない。 & $30(31.6)$ & $1(9.1)$ & $6(35.3)$ & $0(0.0)$ \\
\hline 10) 人間関係は楽。 & $49(51.6)$ & $8(72.7)$ & $12(70.6)$ & $4(57.1)$ \\
\hline 11)上司は信頼できる。 & $45(47.4)$ & $8(72.7)$ & $11(64.7)$ & $5(71.4)$ \\
\hline 12)上司に気を使う。 & $47(49.5)$ & $2(18.2)$ & $11(64.7)$ & $3(42.9)$ \\
\hline 13）勤務時間は適当。 & $73(76.8)$ & $11(100)$ & $8(47.1)$ & $5(71.4)$ \\
\hline 14)勤務は不規則。 & $5(5.3)$ & $0(0.0)$ & $7(41.2)$ & $1(14.3)$ \\
\hline 15)残業が多い。 & $12(12.6)$ & $0(0.0)$ & $10(58.8)$ & $1(14.3)$ \\
\hline 16）早朝勤務がつらい。 & $5(5.3)$ & $0(0.0)$ & $1(5.9)$ & $0(0.0)$ \\
\hline 17)準夜勤務がつらい。 & $3(3.2)$ & $1(9.1)$ & $3(17.6)$ & $0(0.0)$ \\
\hline
\end{tabular}

